$4^{\text {th }}$ International Meeting on Calcitonin Gene-Related Peptide (CGRP)

TheScientificWorld (2001) 1(S1), 26

ISSN 1532-2246; DOI 10.1100/tsw.2001.415

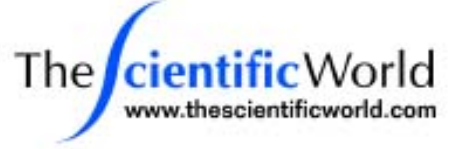

\title{
CAPSAICIN-MEDIATED NEUROGENIC VASODILATATION IN NEUROKININ-1, NK, RECEPTOR KNOCKOUT MICE
}

\author{
A.D. Grant and S.D. Brain \\ Centre for Cardiovascular Biology and Medicine, New Hunt's House, Guy's Campus, King's \\ College, London, SE1 1UL, U.K.
}

Capsaicin induces tachykinin $\mathrm{NK}_{1}$ receptor-dependent neurogenic oedema in the mouse ear and this model has been used to determine the absence of $\mathrm{NK}_{1}$ receptors in $\mathrm{NK}_{1}$ knockout $\left(\mathrm{NK}_{1-/-}\right)$ mice[1]. We have now simultaneously measured neurogenic vasodilatation and oedema in the ear.

Wild-type and $\mathrm{NK}_{1}-/-\mathrm{Sv} 129+\mathrm{C} 57 \mathrm{BL} / 6$ mice were used in this study. Anaesthesia (urethane, $25 \% \mathrm{w} / \mathrm{v} ; 100 \mathrm{ml} / 10 \mathrm{~g}$ ) was induced. Oedema was assessed by the accumulation of ${ }^{125} \mathrm{I}$ albumin, and blood flow by laser Doppler flowmetry. Responses were measured for $1 \mathrm{~h}$ after topical application of capsaicin to one ear and vehicle to the contralateral ear. Capsaicin induced oedema in wild-type Sv129+C57BL/6 mice $(p<0.001)$, but not in $\mathrm{NK}_{1}-/-$ mice, as expected[2]. However, neurogenic vasodilatation $(p<0.05)$ was observed in both wild-type and $\mathrm{NK}_{1-} /-$ mice, and remained in wild-type mice in the presence of the $\mathrm{NK}_{1}$ antagonist SR140333 (480 nmol/ $\mathrm{kg}$ ). Interestingly, increased blood flow in the $\mathrm{NK}_{1}-/-$ mice was significantly $(p<0.05)$ greater than that in the wild-type mice. It was substantially blocked in $\mathrm{NK}_{1}-/-$ mice pretreated with the CGRP antagonist CGRP ${ }_{8-37}(400 \mathrm{nmol} / \mathrm{kg})$, or wild-type mice treated with both SR140333 and CGRP ${ }_{8-37}$, but not in wild-type mice treated with $\mathrm{CGRP}_{8-37}$ alone.

The results suggest that neurogenic vasodilatation is a consequence of CGRP and $\mathrm{NK}_{1}$ receptor mediated responses in the mouse. They also indicate that some form of interaction between functional CGRP and $\mathrm{NK}_{1}$ receptors may occur.

A.D. Grant is supported by a BHF studentship.

\section{REFERENCES}

1. Bozic, C., Lu, B., Hopken, U.E., et al. (1996) Science 273, 1722-1725.

2. Cao, T., Gerard, N.P., and Brain, S.D. (1999) Am. J. Physiol. 277, 476-481. 

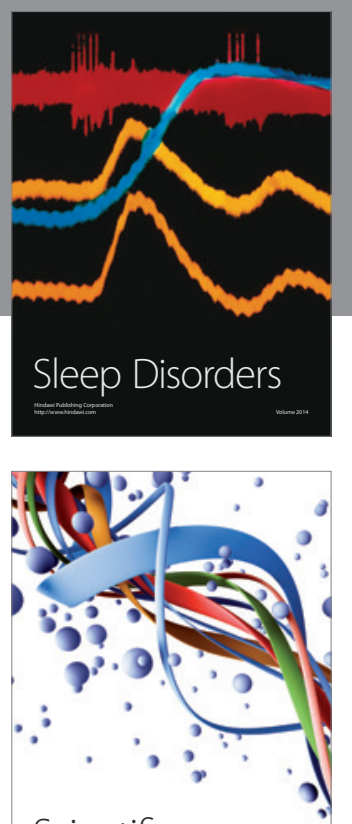

Scientifica
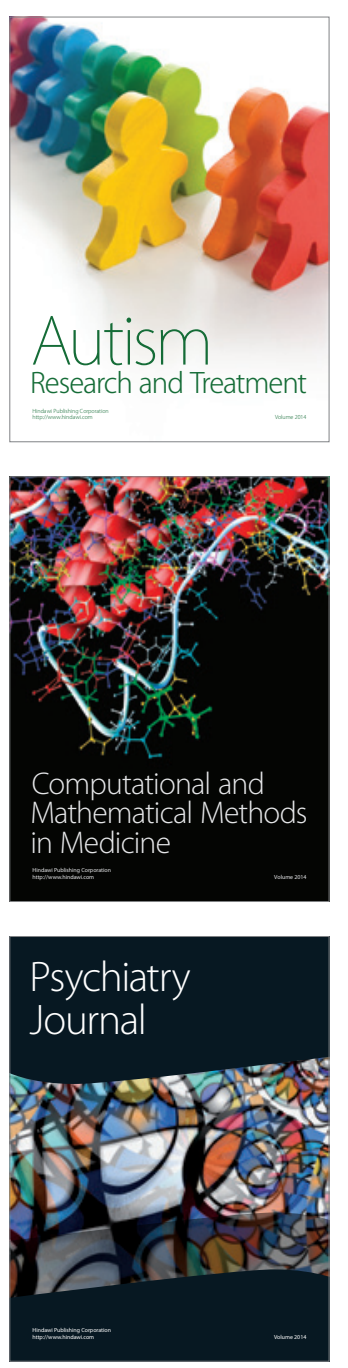
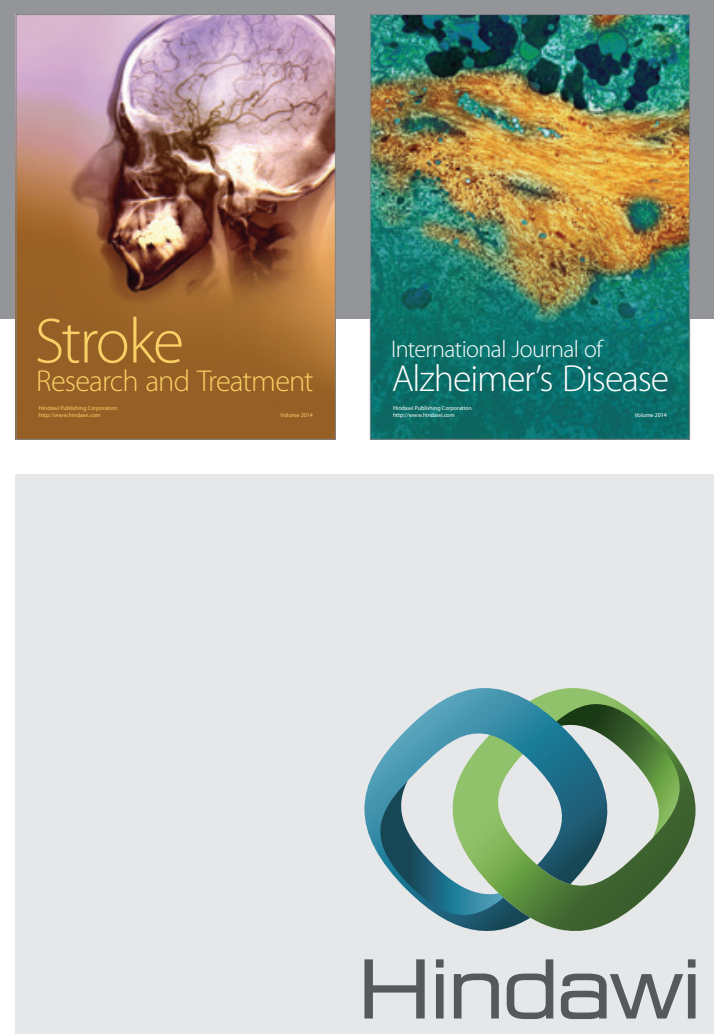

Submit your manuscripts at

http://www.hindawi.com
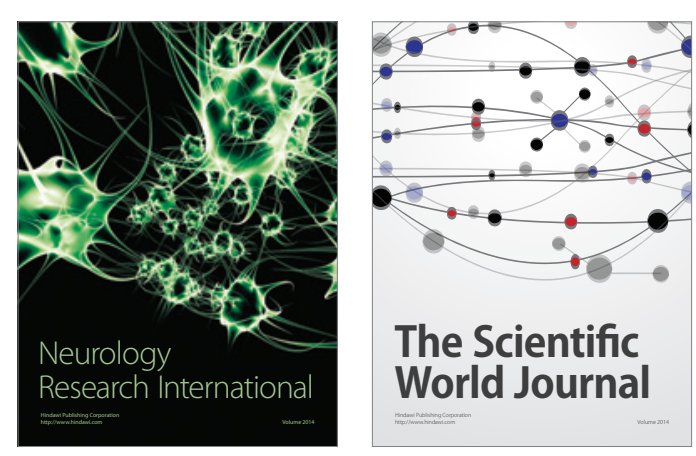

The Scientific World Journal

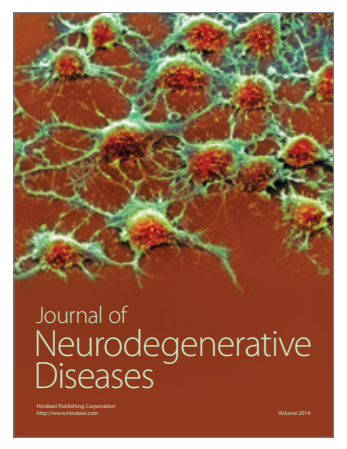

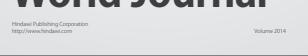

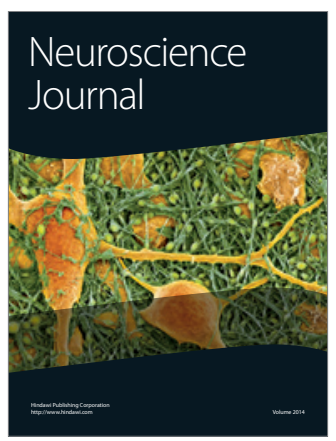

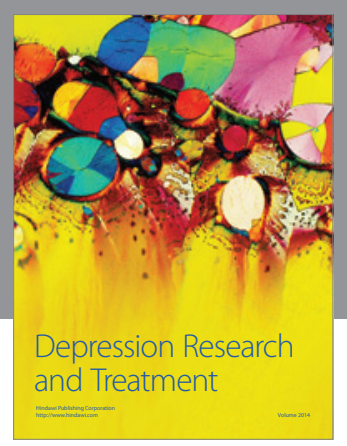
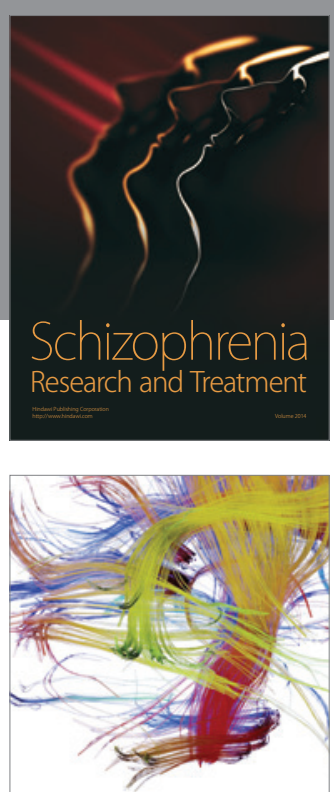

Brain Science

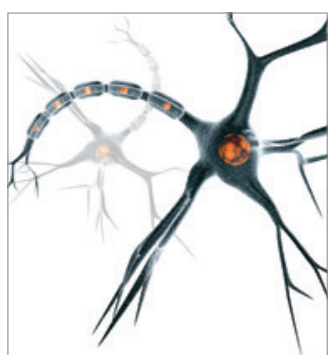

Neural Plasticity
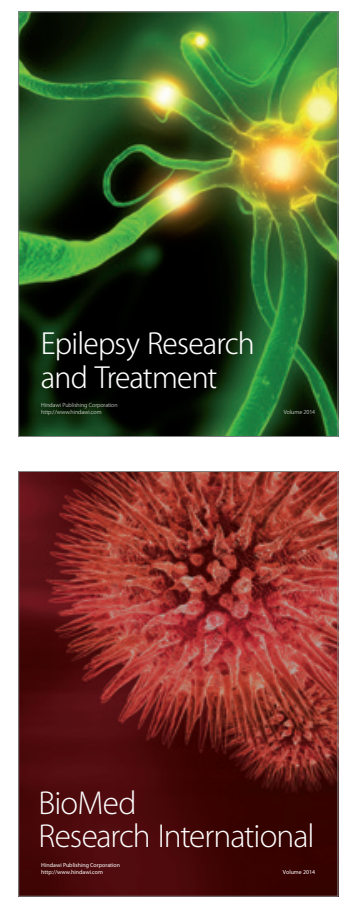

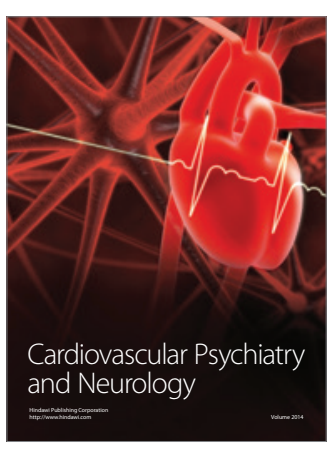

Parkinson's

Disease
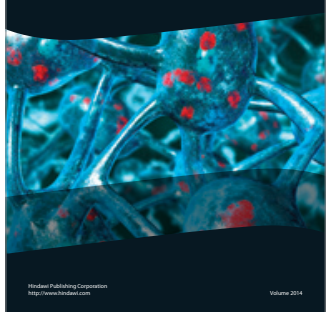